\title{
Distribution and prevalence of crown rot pathogens affecting wheat crops in southern Chile
}

\author{
Ernesto Moya-Elizondo ${ }^{1 *}$, Nolberto Arismendi ${ }^{1}$, María Paz Castro², and Herman Doussoulin ${ }^{2}$
}

\begin{abstract}
Crown rot pathogens are associated with higher losses for wheat crop farmers, but information about the distribution and prevalence of these pathogens in Chile is inadequate. Distribution and prevalence of wheat (Triticum aestivum L.) crown rot pathogens were examined in a survey of 48 commercial fields from December 2011 to February 2012 in southern Chile. These fields were located between Collipulli (3756’00" S; 72²6’39” W) and Purranque (4050’30" S; 73²2’03” W). Severity of crown rot disease was determined through visual assessment of the first internode of 20 tillers obtained from each field. Incidence of crown rot pathogens per field was determined by plating the 20 tillers on Petri plates with $20 \%$ potato dextrose agar amended with lactic acid (aPDA) medium. Resulting fungal colonies from monoxenic culture were identified by morphological or molecular-assisted identification. Severity of crown rot varied between $11.3 \%$ and $80 \%$ for individual fields. Culture plate analysis showed $72.2 \%$ of stems were infected with some fungus. Fusarium avenaceum, F. graminearum, and F. culmorum, pathogens associated with Fusarium crown rot disease were isolated from $13.5 \%$ of tillers. Gaeumannomyces graminis, causal agent of take-all disease in cereals, was isolated from $11.1 \%$ of culms. Phaeosphaeria sp., an endophyte and possibly a non-pathogenic fungus, was isolated from $13.9 \%$ of tillers. Pathogenic fungi such as Rhizoctonia spp. and Microdochium nivale, other saprophyte, and several unidentified non-sporulating fungi were isolated at frequencies lower than $3 \%$ of the total. Fusarium crown rot and take-all were the most prevalent and distributed crown rot diseases present in wheat crops in southern Chile.
\end{abstract}

Key words: Fusarium crown rot, soilborne diseases survey, take-all, Triticum aestivum, wheat diseases.

\section{INTRODUCTION}

Soilborne pathogens cause important diseases in wheat (Triticum aestivum L.) and other cereals, resulting in yield losses, stand reductions, white-heads, and rotting of root, crown, subcrown, and lower stem tissues of seedling and mature plants. Among the pathogens affecting crown and roots of wheat plants, soilborne fungus Gaeumannomyces graminis (Sacc) Arx \& D.L. Oliver var. tritici J. Walker is probably the most damaging disease affecting root and crowns of wheat in Chile (Andrade et al., 2011); it has been recognized as the root and crown disease causing the highest losses for Chilean wheat crop farmers and several studies have been conducted to manage this disease (Madariaga and Mellado, 1998; Andrade, 2004). Recently, G. graminis var. avenae (E.M. Turner) Dennis was described as affecting oat in Chile (Gutiérrez et al.,

${ }^{1}$ Universidad de Concepción, Facultad de Agronomía, Av. Vicente Méndez 595, Chillán, Chile.

*Corresponding author (emoya@udec.cl).

${ }^{2}$ Universidad Austral de Chile, Facultad de Ciencias Agrarias, Campus Isla Teja, Casilla 567, Valdivia, Chile.

Received: 5 August 2014.

Accepted: 16 December 2014.

doi:10.4067/S0718-58392015000100011
2007); however, this pathogen also may affect wheat (Rachdawong et al., 2002).

Another group of important soilborne pathogens are the members of the Fusarium complex, which are responsible of the Fusarium crown and root rot (FCR) disease of wheat. This disease is caused by different pathogen species of the genera Fusarium, which includes primarily Fusarium culmorum (Wm.G. Sm.) Sacc., F. graminearum Schwabe (=Gibberella zeae (Schwein.) Petch) and F. pseudograminearum (O'Donnell \& T. Aoki; group I) (=G. coronicola $\mathrm{T}$. Aoki \& O'Donnell) (Paulitz et al., 2002; Cook, 2010). In other regions, $F$. avenaceum (Fr.: Fr.) Sacc., F . acuminatum Ellis \& Everh., F. equiseti (Corda) Sacc., Microdochium nivale (Fr.: Fr.) Samuels \& I.C. Hallett, and several Fusarium spp. have also been included and reported in the crown rot disease complex in wheat but are considered as less virulent and more environmentally or geographically restricted than the first three species (Cook, 2010). All these species, except $F$. pseudograminearum, have been reported in Chile (Acuña, 2008). Other important species of pathogens reported in Chile with the potential to affect seedlings, crowns, and culms are Bipolaris sorokiniana (Sacc.) Shoemaker, Oculimacula yallundae (Wallwork \& Spooner) Crous \& W. Gams, and Rhizoctonia spp., which cause the diseases 
called common root rot, eyespot, and Rhizoctonia root rot in wheat, respectively (Acuña, 2008).

The pathogens affecting wheat crops can occur singularly or they can co-exist in the same field and even within individual plants (Paulitz et al., 2002). Dominant soilborne pathogen species have a high-level of adaptation in response to changes in temperature, seasonal moisture distribution, amount of moisture, and edaphic factors (Smiley et al., 2005; Moya-Elizondo et al., 2011a). Agricultural concerns with global climate change are associated with the potential threat to food supply, derived from impacts such as changing patterns of rainfall, increasing incidence of extreme weather, and changing distribution and incidence of diseases and their vectors (Soussana et al., 2010). Information from crown rot pathogens surveys in wheat crops associated with georeferenced geographical distribution and environmental data could be used in the future to assess changes associated with global warming (Tunali et al., 2008; Moya-Elizondo et al., 2011a; Moya-Elizondo, 2013). These studies have showed that disease surveys could be a useful tool to monitor the effect of global climate change, considering that soilborne diseases are defined in agroecological zones with records of the distribution, incidence, and prevalence of different crown rot pathogen species (Moya-Elizondo, 2013).

Field surveys of crown rot pathogens on wheat are commonly reported in countries where the greatest amount of wheat crops is produced worldwide and where soilborne diseases cause significant losses. Surveys of soilborne and crown root rot pathogens of wheat have been reported in USA (Strausbaugh et al., 2004; Smiley et al., 2005; Moya-Elizondo et al., 2011a), Canada (Hall and Sutton, 1998; Fernandez et al., 2007), Australia (Scott et al., 2003; Backhouse et al., 2004), United Kingdom (Pettitt et al., 2003), Turkey (Tunali et al., 2008), and Iran (Saremi et al., 2007). In Chile, the most recent and systematic survey was conducted in 1981 by Madariaga and McMahon (1981), when they examined the incidence of the take-all pathogen around the piedmont of the Andes mountains in the Biobío Region. After this work, to our knowledge, there has not been another survey conducted to determine soilborne pathogens in Chile.

Considering the dramatic changes that have been projected with climate change in Chilean agriculture (Meza and Silva, 2009; Neuenschwander, 2010), it is important to generate information about the distribution and actual prevalence of pathogens associated with soilborne and crown rot diseases of wheat associated with this phenomenon; especially considering that this information could be very valuable for determining changes of disease distribution patterns in the future. Due to the need to generate information and understand disease dynamics, this study was conducted to assess the distribution of pathogen populations associated with crown rot disease across commercial wheat fields located in an area that represents the most important agricultural surface dedicated to the production of this cereal in southern Chile.

\section{MATERIAL AND METHODS}

\section{Survey protocols}

A summer survey was conducted on 48 commercial wheat crop fields located between Collipulli (La Araucanía Region) and Purranque (Los Lagos Region) during the crop season 2011-2012. Fields located in this area were selected arbitrarily from collaborative growers and were represented by typical Andisol soils, which are common in this geographic area. No prior knowledge of current disease incidence or severity, or wheat cultivars was considered in their selection. We divided this zone into eight areas with respect to the latitudinal distance of the field inside the sampled area located between coordinates $37^{\circ} 56^{\prime} 00^{\prime \prime}$ and $40^{\circ} 50^{\prime} 30^{\prime \prime} \mathrm{S}$ lat (Table 1). The designation of each area was based with consideration for a minimum of four sample fields and a distance of less than $1.5 \mathrm{~km}$ between them.

Isolates collected from the field survey were obtained from plants in their dough grain stage (Feekes stage 10.1-10.5) or prior to harvest (Feekes stage 11). Each field was sampled following a modified methodology

Table 1. Sampled area, number of fields per area, location antecedents, and assessment of plant parameters and culm rot disease symptoms for field survey conducted in the south of Chile (2011-2012).

\begin{tabular}{|c|c|c|c|c|c|c|c|c|}
\hline \multirow[b]{2}{*}{ Area $^{1}$} & \multirow[b]{2}{*}{ Sampled area } & \multirow[b]{2}{*}{ Region } & \multirow{2}{*}{$\begin{array}{l}\text { Number } \\
\text { of field }\end{array}$} & \multicolumn{2}{|c|}{ GPS location approximated ${ }^{2}$} & \multirow{2}{*}{$\begin{array}{c}\text { Culm per } \\
\text { plant }\end{array}$} & \multirow{2}{*}{$\begin{array}{c}\text { Plant } \\
\text { height } \\
(\mathrm{mm})\end{array}$} & \multirow[b]{2}{*}{$\mathrm{IDSI}^{3}$} \\
\hline & & & & Latitude (S) & Longitude (W) & & & \\
\hline 1 & Collipulli & La Araucanía & 5 & $37^{\circ} 56^{\prime}-37^{\circ} 57^{\prime}$ & $72^{\circ} 26^{\prime}-72^{\circ} 16^{\prime}$ & 2.0 & 100.1 & 41.0 \\
\hline 2 & Quino & La Araucanía & 6 & $38^{\circ} 16^{\prime}-38^{\circ} 20^{\prime}$ & $72^{\circ} 24^{\prime}-72^{\circ} 10^{\prime}$ & 2.3 & 89.9 & 36.9 \\
\hline 3 & Perquenco & La Araucanía & 4 & $38^{\circ} 23^{\prime}-38^{\circ} 26^{\prime}$ & $72^{\circ} 28^{\prime}-72^{\circ} 16^{\prime}$ & 3.4 & 103.8 & 51.9 \\
\hline 4 & Cajón-Temuco & La Araucanía & 5 & $38^{\circ} 39^{\prime}-38^{\circ} 41^{\prime}$ & $72^{\circ} 30^{\prime}-72^{\circ} 29^{\prime}$ & 3.5 & 94.7 & 23.8 \\
\hline 5 & Gorbea & La Araucanía & 4 & $39^{\circ} 04^{\prime}-39^{\circ} 07^{\prime}$ & $72^{\circ} 40^{\prime}-72^{\circ} 40^{\prime}$ & 3.5 & 95.3 & 32.9 \\
\hline 6 & Máfil-Valdivia & Los Ríos & 7 & $39^{\circ} 32^{\prime}-39^{\circ} 43^{\prime}$ & $73^{\circ} 14^{\prime}-72^{\circ} 55^{\prime}$ & 1.7 & 84.4 & 33.8 \\
\hline 7 & Paillaco-Futrono & Los Ríos & 10 & $39^{\circ} 51^{\prime}-40^{\circ} 08^{\prime}$ & $72^{\circ} 48^{\prime}-72^{\circ} 26^{\prime}$ & 2.2 & 89.5 & 45.7 \\
\hline \multirow[t]{2}{*}{8} & Trumao-Osorno & Los Lagos & 7 & $40^{\circ} 30^{\prime}-40^{\circ} 50^{\prime}$ & $73^{\circ} 08^{\prime}-73^{\circ} 22^{\prime}$ & 1.7 & 100.9 & 52.3 \\
\hline & Total & & 48 & $37^{\circ} 56^{\prime}-40^{\circ} 50^{\prime}$ & $73^{\circ} 08^{\prime}-72^{\circ} 16^{\prime}$ & 2.5 & 94.8 & 39.8 \\
\hline
\end{tabular}

${ }^{1}$ Areas were assigned according to the distance between locations and these areas considered over four fields associated with each location.

${ }^{2}$ GPS locations were obtained using GPS equipment Venture Cx Garmin e-tex and corroborated by using Google Earth ${ }^{\circledR}$ software.

${ }^{3}$ IDSI: Internodes discoloration severity index, where the scale included six classes $(0-5)$ where $0=$ no infected internode, $1=<25 \%$ of infected internode, $2=25 \%-50 \%$ of infected internode, $3=50 \%-75 \%$ of infected internode, $4=75 \%-100 \%$ of infected internode, and $5=>100 \%$ or infection in upper internodes. The IDSI for each field was then calculated as: IDSI $=[\Sigma$ (class value $\times$ frequency $) /($ total number of plants $\times$ the highest class value $)] \times 100($ Hogg et al., 2007$)$. 
as that described by Moya-Elizondo et al. (2011a). The sample consisted of 60 plants with intact roots $(10 \mathrm{~cm}$ depth). Samples were collected from the field at 20 sites along a $600 \mathrm{~m}$ diagonal transect, with each site being approximately $30 \mathrm{~m}$ apart. Transect directions were variable, always starting $30 \mathrm{~m}$ from the margin of the field and were representative of the field.

\section{Disease prevalence and crop damage assessment}

Collected plants during the survey were counted, separated, and washed. Then, 20 tillers were randomly selected to assess disease incidence and severity. Incidence was determined by counting the number of symptomatic tillers from the total number of collected plants in each sample site. Severity was determined by using a crown rot rating scale of 0 to 5 for the culmdarkness on the first internode of each tiller, where $0=$ no infected internode, $1=<25 \%$ infected internode, 2 $=25 \%-50 \%$ infected internode, $3=50 \%-75 \%$ infected internode, $4=75 \%-100 \%$ infected internode, and $5=$ $>100 \%$ infection in upper internodes. An internode discoloration severity index (IDSI) was calculated by summing the number of plants in each category class multiplied by the value of each category and dividing this sum by the total number of plants $\times 6$ (the number of categories), then multiplying by 100 to create an IDSI for each sample (Hogg et al., 2007). Additionally, measurements of plant characteristics included counting the number of tillers, including head and culm height of the 20 plants. Collected heads were used to determine grain weight and kernel weight.

\section{Isolation and identification of pathogens}

The 20 tillers arbitrarily selected for the assessment of disease were used to determine the root and crown rot pathogens involved in the infection of the stems obtained from each field. Segments of $3 \mathrm{~mm}$ were removed from the basal part of the first internodes of the selected wheat tillers and were used to assess fungal pathogen species through culturing on a general media of $20 \%$ potato dextrose agar amended with lactic acid (aPDA). Prior to plating, stem segments were disinfected in sodium hypochlorite at $0.54 \%$ during $1 \mathrm{~min}$ and rinsed three times in sterile distilled water. Five disinfected segments were placed on each aPDA plate. Plates were incubated at $24 \pm 1{ }^{\circ} \mathrm{C}$ and monitored daily for fungal growth. Resulting fungal colonies were re-isolated on PDA to develop monoxenic cultures by taking hyphal tips. All resulting isolates were identified to their genus using morphologic and culture characteristics and traditional species identification keys (Nelson et al., 1983; Barnett and Hunter, 2006). Fusaria species were identified as described by Moya-Elizondo et al. (2011a).

Due to the difficulty in identifying some isolates based on morphology, unknown isolates were differentiated by color and morphology in plates with PDA. They were grouped according to similar characteristics and the DNA of one or two isolates was extracted for amplification. Identification of the fungus was confirmed by molecular characterization of the Internal Transcribed Spacer (ITS) and 18SrRNA regions (universal primers ITS4/5 and NS1/2, respectively) (Daval et al., 2010) and the gene $\beta$-tubulin (primers Bt1a/Bt1b) (Glass and Donaldson, 1995). DNA isolation from culture was conducted following protocols described by Montalva et al. (2014). Total (genomic and mitochondrial) DNA was used. PCR assays were conducted in a volume of $25 \mu \mathrm{L}$ per sample in duplicates. Each sample contained $1 \times$ PCR buffer, $2 \mathrm{mM} \mathrm{MgCl} 2,200 \mu \mathrm{M}$ dNTP, $0.4 \mu \mathrm{M}$ of each primer, $2 \mathrm{U}$ taq DNA polymerase (Invitrogen, Carlsbad, California, USA), sterile distilled water, and 25 to $50 \mathrm{ng}$ $\mu \mathrm{L}^{-1}$ of isolated fungal DNA. The thermal profile of the 35 cycles of PCR (MultiGene Gradient Thermal Cycler TC9600-G, Labnet International, Edison, New Jersey, USA) consisted of the initial step at $94{ }^{\circ} \mathrm{C}$ for $3 \mathrm{~min}$, followed by 35 cycles at $94^{\circ} \mathrm{C}$ for $30 \mathrm{~s}$, considering $50^{\circ} \mathrm{C}$ for $18 \mathrm{sF} 2 / \mathrm{pITS} 4$ primers or $57^{\circ} \mathrm{C}$ for $\mathrm{Bt} 1 \mathrm{a} / \mathrm{Bt} 1 \mathrm{~b}$ primers for $40 \mathrm{~s}$, and $72{ }^{\circ} \mathrm{C}$ for $60 \mathrm{~s}$ and the final step at $72{ }^{\circ} \mathrm{C}$ for 5 min. PCR products were run in $1 \%$ agarose gels with $0.1 \mu \mathrm{L} \mathrm{mL} \mathrm{m}^{-1}$ of ethyl bromide in $0.5 \times$ TBE buffer at 100 $\mathrm{V}$ for $30 \mathrm{~min}$. PCR amplicon products were observed and photographed on a UV light transilluminator. Fragments isolated from the unknown isolates were submitted for sequencing by Macrogen Inc. (Seoul, Korea). DNA sequences were performed using BLAST searches for homologous sequences in the public databases at the National Center for Biotechnology Information (NCBI, Bethesda, Maryland, USA) (Altschul et al., 1990). Isolates suspected to be $F$. graminearum o F. pseudograminearum species were corroborated by using the specific primers described by Aoki and O'Donnell (1999) and following the PCR protocols described by Scott et al. (2003), while isolates considered to be a different variety of $G$. graminis were identified by using the specific primers and protocols described by Fouly and Wilkinson (2000).

The number and identity of fungal species were recorded for each field. These data were used to correlate relationships between isolation frequencies and the crop damages determined for each field.

\section{Data analysis}

Descriptive statistics were used to determine percentages of IDSI and incidence of isolated pathogens. Spearman's correlation coefficient analysis was performed to examine various relationships between disease and pathogen populations and to measure plant characteristics and determine yield parameters using the package "Rcmdr" of the R-Software (R Foundation for Statistical Computing, Vienna, Austria). Spearman's coefficient of rank correlation was used to avoid variance differences and the distribution effect of analyzed variables. 


\section{RESULTS AND DISCUSSION}

The survey conducted between Collipulli (La Araucanía Region) and Purranque (Los Lagos Region) determined the prevalence of pathogen species affecting wheat crops during late stages of growth. Results for culm height and number of tillers plus the severity of possible disease expressed as IDSI values for each area are showed in Table 1. Differences were observed in the culm height and number of tillers for the different sampled areas. However, variability can be explained by the different cultivars and agronomic practices used by the farmers in each field. Range of IDSI values in the sampled fields varied between $11.3 \%$ and $80 \%$ for a field located in Valdivia $\left(39^{\circ} 69^{\prime} \mathrm{S}, 72^{\circ} 95^{\prime} \mathrm{W}\right)$ and Osorno $\left(40^{\circ} 59^{\prime} \mathrm{S}\right.$, $\left.73^{\circ} 21^{\prime} \mathrm{W}\right)$, respectively. The area with high levels of severity associated with crown and root rot pathogens was observed in the area of Trumao-Osorno in Los Lagos Region, while the area of Cajón-Temuco showed fields with lower severity levels. Interestingly, in this area we have isolated bacterial populations of Pseudomonas spp. associated with the production of 2,4-diacetylphloroglucinol (Moya-Elizondo et al., 2013), which are related within suppressive soils to wheat root rot diseases (Kwak et al., 2009).

Considering that the discoloration of the first internode can be due to diverse causes, we took a piece $2 \mathrm{~mm}$ in length off the base of these first internodes of 20 selected tillers for each field to isolate the possible pathogens involved; $72.2 \%$ of the plated tiller pieces showed evidence of isolated fungi $(\mathrm{n}=960)$, which included 11 culms that showed infestation by two fungi (Table 2). Fungi identified as $G$. graminis were isolated in $11.1 \%$ of the field, and this pathogen was more common in the areas of MáfilValdivia and Trumao-Osorno, where the variety tritici was the most common (68 isolates). Among this percentage of G. graminis, we identified seven isolates of the variety avenae by PCR. Gaeumannomyces graminis var. avenae was recently found in Chile (Gutiérrez et al., 2007) and its distribution and importance in the area of cereal production in Chile will require further study. Pathogens from genus Fusarium were the most common followed by Phaeosphaeria spp., which at first were confused for Tapesia spp., pathogens associated with Eyespot disease of wheat, or G. graminis var. tritici responsible for takeall disease, but PCR amplification and sequencing of ITS, $18 \mathrm{~S}$ and $\beta$-tubulin genes determined that those isolated fungi were Phaeosphaeria pontiformis (Fuckel) Leuchtm (Gen-Bank accession FN386303.1), which are described as endophytes in mature wheat plants (Moya-Elizondo et al., 2011a) and other Poaceae species (Van Ryckegem and Verbeken, 2005). Genus Phaeosphaeria is the teleomorph stage of Stagonospora spp., which is associated with disease in wheat and other cereals (Agrios, 2005).

Around $8.2 \%$ of the isolated fungi did not produce morphological structures that allow their identification. Other species of saprophytic and pathogenic fungi from genera such as Rhizoctonia, Sclerotinia, Trichoderma, Alternaria, Torula, Penicillium, Nigrospora, and Colletotrichium were also isolated. However, the level of significance was low despite together representing $11 \%$ of the total fungi isolated.

Considering the importance of fusaria in the total of isolated species, we completed their identification based on the use of taxonomic clues described by Nelson et al. (1983), and supported sometimes by PCR with specific primers. We determined different species of Fusarium, such as $F$. oxysporum, $F$. avenaceum, $F$. graminearum, and $F$. culmorum (Table 3; Figure 1), which are common pathogens of wheat and are associated with FCR and Fusarium scab of wheat (Paulitz et al., 2002). Fusarium avenaceum, $F$. acuminatum, and $F$. culmorum are common pathogens in cold and wet climates (Hall and Sutton, 1998; Pettitt et al., 2003), which are common environmental conditions in the sampled area. These conditions can explain $1.4 \%$ incidence of $F$. avenaceum

Table 2. Percentage of pathogens and the most common genera of fungus isolated from pieces of the first internode of commercial wheat crops located in eight areas in the south of Chile during the season 2011-2012.

\begin{tabular}{|c|c|c|c|c|c|c|c|c|c|}
\hline \multirow[b]{2}{*}{ Area } & \multirow[b]{2}{*}{ Sampled area ${ }^{1}$} & \multirow[b]{2}{*}{ Region } & \multirow[b]{2}{*}{$\begin{array}{l}\text { Number } \\
\text { of field }\end{array}$} & \multicolumn{6}{|c|}{ Percentage of isolated pathogens } \\
\hline & & & & $\mathrm{Ggt}^{2}$ & Fus $^{3}$ & $\mathrm{Phae}^{4}$ & Unknown $^{5}$ & $\begin{array}{l}\text { Other } \\
\text { fungi }{ }^{6}\end{array}$ & $\begin{array}{c}\text { Not } \\
\text { infested }^{7}\end{array}$ \\
\hline 1 & Collipulli & La Araucanía & 5 & 1.5 & 2.1 & 3.2 & 0.9 & 1.4 & 1.7 \\
\hline 2 & Quino & La Araucanía & 6 & 1.5 & 3.7 & 2.1 & 0.5 & 1.5 & 3.2 \\
\hline 3 & Perquenco & La Araucanía & 4 & 0.9 & 1.1 & 2.9 & 0.1 & 0.2 & 3.1 \\
\hline 4 & Cajón-Temuco & La Araucanía & 5 & 0.4 & 2.8 & 0.8 & 1.4 & 0.6 & 4.4 \\
\hline 5 & Gorbea & La Araucanía & 4 & 0.6 & 2.8 & 0.4 & 0.6 & 0.7 & 3.2 \\
\hline 6 & Máfil-Valdivia & Los Ríos & 7 & 2.7 & 2.5 & 1.5 & 1.4 & 1.1 & 5.6 \\
\hline 7 & Paillaco-Futrono & Los Ríos & 10 & 1.0 & 9.0 & 0.6 & 2.5 & 4.6 & 3.4 \\
\hline \multirow[t]{2}{*}{8} & Trumao-Osorno & Los Lagos & 7 & 2.5 & 5.0 & 2.3 & 0.8 & 0.9 & 3.1 \\
\hline & Total & & 48 & 11.1 & 20.8 & 13.9 & 8.2 & 11.0 & 27.8 \\
\hline
\end{tabular}

${ }^{1}$ Areas were assigned according to the distance between locations and these areas considered over four fields associated with each location.

${ }^{2} \mathrm{Ggt}$ : Gaeumannomyces graminis is a complex of fungus causing take-all disease of wheat.

${ }^{3}$ Fus: Fungal species of genus Fusarium.

${ }^{4}$ Phae: Phaeosphaeria sp., is an endophyte fungi observed in mature culms of wheat plants. The fungus is considered non-pathogenic.

${ }^{5}$ Unknown: Species of mycelia sterilia fungi. They did not produce conidia or structures to identify.

${ }^{6}$ Other fungi: Considered pathogenic fungal species such as Rhizoctonia spp. and Sclerotinia spp., or saprophyte or weak pathogens such as Trichoderma spp.,

Colletotrichium spp., etc.

${ }^{7}$ Not infested: Considered culms pieces without presence of fungal growth. 
Table 3. Percentage of fusaria pathogens isolated from pieces of the first internode of commercial wheat crops located in eight areas in the south of Chile during the season 2011-2012.

\begin{tabular}{|c|c|c|c|c|c|c|c|c|c|c|}
\hline \multirow[b]{2}{*}{ Sampled area ${ }^{1}$} & \multirow[b]{2}{*}{ Region } & \multirow{2}{*}{$\begin{array}{l}\text { Number } \\
\text { of fields }\end{array}$} & \multicolumn{8}{|c|}{ Percentage of fusaria species ${ }^{2}$} \\
\hline & & & Faven & Fculm & Fgr & Fsol & Mniv & Foxy & Fdim & Fspp \\
\hline Collipulli & La Araucanía & 5 & 0.4 & 0.0 & 0.2 & 0.1 & 0.4 & 0.8 & 0.1 & 0.2 \\
\hline Quino & La Araucanía & 6 & 1.3 & 0.1 & 0.7 & 0.0 & 0.4 & 0.7 & 0.3 & 0.7 \\
\hline Perquenco & La Araucanía & 4 & 0.5 & 0.0 & 0.1 & 0.0 & 0.0 & 0.0 & 0.0 & 0.5 \\
\hline Cajón-Temuco & La Araucanía & 5 & 0.8 & 0.0 & 0.9 & 0.0 & 0.2 & 0.3 & 0.1 & 0.6 \\
\hline Gorbea & La Araucanía & 4 & 0.4 & 0.0 & 0.1 & 0.1 & 0.9 & 0.9 & 0.2 & 0.3 \\
\hline Máfil-Valdivia & Los Ríos & 7 & 0.1 & 0.6 & 0.2 & 0.1 & 0.1 & 0.7 & 0.1 & 0.6 \\
\hline Paillaco-Futrono & Los Ríos & 10 & 1.4 & 1.0 & 1.1 & 0.1 & 0.5 & 4.5 & 0.9 & 0.7 \\
\hline Trumao-Osorno & Los Lagos & 7 & 0.6 & 1.7 & 1.1 & 0.2 & 0.4 & 0.6 & 0.1 & 0.7 \\
\hline Total & & 48 & 5.5 & 3.4 & 4.6 & 0.6 & 3.0 & 8.6 & 1.9 & 4.5 \\
\hline
\end{tabular}

${ }^{1}$ Areas were assigned according to the distance between locations and these areas considered over four fields associated with each location.

${ }^{2}$ Fusarium species isolated: Faven: F. avenaceum; Fculm: F. culmorum; Fgr: F. graminearum; Fsol: F. solani; Mniv: Microdochium nivale; Foxy: F. oxysporum; Fdim: F. dimerum; and Fspp: other uncommon Fusarium species, which are saprophyte or weak pathogens such as F. acuminatum, F. sporotrichioides, F. scirpi, F. equiseti, F. lateritium, etc.

in the Paillaco-Futrono area and the presence of $F$. culmorum isolates at $1.0 \%$ and $1.7 \%$ rates observed in the cited area and in Trumao-Osorno, respectively. Presence of $F$. pseudograminearum and $F$. graminearum was identified to species level by using specific primers with consideration that both pathogens produce macroconidia and similar colors in PDA. Moreover, we did not observe production of perithecia, which is a typical structure used to identify $F$. graminearum; nevertheless, the teleomorph of $F$. pseudograminearum has been reported producing perithecia under lab conditions (Aoki and O'Donnell, 1999). Fusarium pseudograminearum was not identified in the isolates obtained in this survey and we could consider that this pathogen cannot be present in Chile.

Fusarium acuminatum, $F$. solani, Microdochium nivale, $F$. oxysporum, and $F$. dimerum are saprophytic or weak pathogens in seedlings and culms of wheat, and these fungi were isolated over $0.5 \%$ in tillers. Moreover, other uncommon species of fusaria, which are also saprophyte or weak pathogens of wheat, were isolated. These Fusarium included F. crookwellense, F. sporotrichioides,

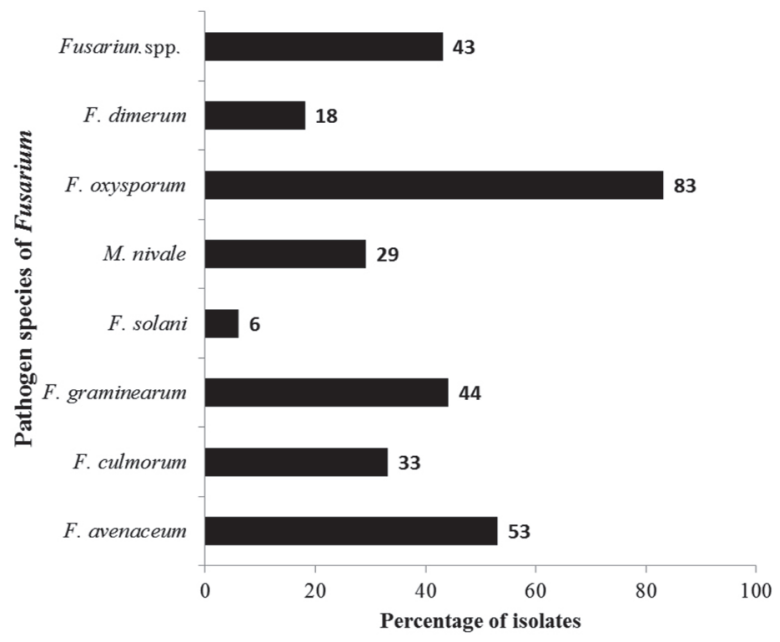

Figure 1. Percentage of main Fusarium species isolate obtained from pieces of the first internode of commercial wheat crops located in eight areas of the south of Chile during the season 2011-2012.
F. scirpi, F. equiseti, and F. lateritium, but they did not raise the two or four isolates from the total.

Almost all species isolated in this survey can cause Fusarium head blight (FHB). However, F. graminearum is the most common cause of head blight and seedling blight of wheat in the USA (Cook, 2010), while F. culmorum is more common in Europe (Wagacha and Muthomi, 2007). Fusarium head blight infections occur under wet or humid conditions at anthesis or shortly thereafter, which are very uncommon weather conditions during anthesis in southern Chile. However, the presence of $F$. graminearum, $F$. avenaceum, and $F$. culmorum in the soils of southern Chile is associated with a change of agronomic practices, such as a rotation of corn in fields cropped with wheat, maintenance of crop residues on the fields by the increased use of non-till practices, or the increased use of sprinkle irrigation to avoid summer drought, and the projection of climatic change could in the future be associated with an increase of FHB epiphytic and problems of mycotoxin contamination of grains. A recent detection of FHB in durum wheat caused by $F$. graminearum and $F$. acuminatum in the Chillan area, Biobío Region (Madariaga et al., 2013) could support that epiphyte of FHB are going to be a common problem in wheat production in the future. On the other hand, considering that FCR is favored by water stress late in the growth season (Paulitz et al., 2002), an increased number of summer drought conditions in the area located from the Biobío Region to the south will probably increase the occurrence of this disease, as has been suggested by Moya-Elizondo (2013); especially, considering that three of the most important fungi associated with FHB and FCR were recurrently isolated during this survey.

There were positive correlations detected between IDSI or severity of the crown rot diseases in culms expressed by the incidence of $G$. graminis species and Phaeosphaeria spp. (rho-Sperman: 0.321, p = 0.026, and rho-Sperman: $0.408, \mathrm{p}<0.001$, respectively). This suggests that both fungi could be interacting to cause darkening of the first internode and support the positive correlation between both pathogens in their incidences 
(rho-Sperman: 0.288, $\mathrm{p}=0.047$ ). However, a correlation was not observed among each individual pathogen on some of the assessed plant and yield parameters. IDSI had a negative relationship with culm number (rhoSperman: $-0.3086, p=0.033$ ), suggesting that damage or the presence of darkening in the first internode should translate in a lower number of tillers. Also, a positive correlation was found between the population of $F$. avenaceum and $F$. graminearum (rho-Sperman: 0.330, $\mathrm{p}=$ 0.022 ). Furthermore, we found a low negative correlation between the incidence of $G$. graminis species and $F$. graminearum (rho-Sperman: -0.257, $\mathrm{p}=0.078$ ), which implies that fungi adapted to drier conditions like fusaria could fill the ecological niche of Gaeumannomyces under environmental conditions of increased drought associated with climatic change. Studies of interaction between Bipolaris sorokiniana and $F$. pseudograminearum have determined the ability and prevalence of Fusarium species to colonize the first internode over other pathogens like $B$. sorokiniana, which also colonize the same microecological niche in wheat plants under drier conditions (Moya-Elizondo et al., 2011b). Fusarium culmorum, a pathogen of the Fusarium crown rot complex adapted to cold conditions, had a negative correlation with the number of tillers and spikes (rho-Sperman: $-0.395, \mathrm{p}=$ 0.006 , and rho-Sperman: $-0.329, p=0.026$, respectively).

The majority of crown and root rot disease wheat surveys have been conducted in more than one sampling season, to observe the effect of environmental conditions in the expression of the involved pathogens in the area under study. This survey was only performed in one crop season, but the conditions of the year 2011 were associated with temperatures not different from an average year (INE, 2013). However, precipitation was reduced approximately $6.8 \%, 12.5 \%$, and $23.1 \%$ with respect to an average year in the area of Temuco, Valdivia, and Osorno, respectively (INE, 2013). These drier conditions in the sampling area could explain the higher prevalence of FCR pathogens. This survey is a first effort to recognize the spatial epidemiological importance of the crown and root rot diseases affecting wheat in Chile, and these results could be valuable information for the future considering the dramatic scenario predicted for climatic change in Chilean agriculture.

\section{CONCLUSIONS}

The distribution and prevalence of wheat crown rot pathogens was studied through a survey of commercial fields in southern Chile (Collipulli to Purranque). Severity of crown rot disease varied between individual fields and $72.2 \%$ of stems were infected with some fungus. Phaeosphaeria sp., an endophyte and possibly a nonpathogenic fungus, was isolated repeatedly from tiller in dough and mature stages of wheat plants. Pathogenic fungi such as Rhizoctonia spp., Microdochium nivale, other saprophyte and several unidentified, non-sporulating fungi were isolated in the lowest frequency. Pathogens associated with fusarium crown rot and take-all diseases were the most prevalent and distributed crown rot diseases present in wheat crops in southern Chile.

\section{ACKNOWLEDGEMENTS}

The author would like to recognize that this research was funded by the Comisión Nacional de Investigación Científica y Tecnológica (CONICYT) through Fondo Nacional de Desarrollo Científico y Tecnológico (FONDECYT) grant nr 11110105.

\section{LITERATURE CITED}

Acuña, R. 2008. Compendio de fitopatógenos de cultivos agrícolas en Chile. 123 pp. Servicio Agrícola y Ganadero (SAG), División Protección Agrícola, Santiago, Chile.

Agrios, G.N. 2005. Plant pathology. $5^{\text {th }}$ ed. 922 p. Elsevier Academic Press Publications, San Diego, California, USA.

Altschul, S., W. Gish, W. Miller, E. Myers, and D. Lipman. 1990. Basic local alignment search tool. Journal of Molecular Biology 215:403-410. doi:10.1016/S0022-2836(05)80360-2.

Andrade, O. 2004. Efectividad de diferentes desinfectantes de semilla sobre la pudrición radical (Gaeumannomyces graminis var. tritici) del trigo en el sur de Chile. Agricultura Técnica (Chile) 64:111-126.

Andrade, O., R. Campillo, A. Peyrelongue, and L. Barrientos. 2011. Soils suppressive against Gaeumannomyces graminis var. tritici identified under wheat crop monoculture in southern Chile. Ciencia e Investigación Agraria 38:345-356.

Aoki, T., and K. O'Donnell. 1999. Morphological and molecular characterization of Fusarium pseudograminearum sp. nov., formerly recognized as the Group I population of F. graminearum. Mycologia 91:597-609.

Backhouse, D.A., A. Abubakar, L.W. Burgess, J.I. Dennis, G.J. Hollaway, G.B. Wildermuth, et al. 2004. Survey of Fusarium species associated with crown rot of wheat and barley in eastern Australia. Australasian Plant Pathology 33:255-261.

Barnett, H.L., and B.B. Hunter. 2006. Illustrated genera of imperfect fungi. $4^{\text {th }}$ ed. American Phytopathological Society, St. Paul, Minnesota, USA.

Cook, R.J. 2010. Fusarium root, crown, and foot rots and associated seedling diseases. p. 37-39. In Bockus, W.W., R. Bowden, R. Hunger, W. Morrill, T. Murray, and R. Smiley (eds.) Compendium of wheat diseases and pests. $3^{\text {rd }}$ ed. The Pennsylvania State University Press, University Park, Pennsylvania, USA.

Daval, S., L. Lebreton, K. Gazengel, A.Y. Guillerm-Erckelboudt, and A. Sarniguet. 2010. Genetic evidence for differentiation of Gaeumannomyces graminis var. tritici into two major groups. Plant Pathology 59:165-178.

Fernandez, M.R., P. Basnyat, and R.P. Zentner. 2007. Response of common root rot in wheat to crop management in eastern Saskatchewan. Canadian Journal of Plant Science 87:953-963.

Fouly, H.M., and H.T. Wilkinson. 2000. Detection of Gaeumannomyces graminis varieties using polymerase chain reaction with variety-specific primers. Plant Disease 84:947-951.

Glass, N.L., and G.C. Donaldson. 1995. Development of primer sets designed for use with the PCR to amplify conserved genes from filamentous Ascomycetes. Applied and Environmental Microbiology 61:1323-1330.

Gutiérrez, M., C. Asenjo, O. Oyarzo, y P. Peña. 2007. Identificación de Gaeumannomyces graminis var. avenae (E.M. Turner) Dennis un nuevo patógeno de avena en Chile. XVII Congreso Nacional de Fitopatología, Concepción, Chile. 27-30 November 2007. Abstract. 
Hall, R., and J.C. Sutton. 1998. Relation of weather, crop, and soil variables to the prevalence, incidence, and severity of basal infections of winter wheat in Ontario. Canadian Journal of Plant Pathology 20:69-80.

Hogg, A., R. Johnston, and A. Dyer. 2007. Applying real-time quantitative PCR to Fusarium crown rot of wheat. Plant Diseases 91:1021-1028.

INE. 2013. Medio ambiente. Informe Anual 2011. 230 p. Instituto Nacional de Estadística (INE), Santiago, Chile.

Kwak, Y.-S., P.A. Bakker, D.C. Glandorf, J.T. Rice, T.C. Paulitz, and D.M. Weller. 2009. Diversity, virulence, and 2,4-diacetylphloroglucinol sensitivity of Gaeumannomyces graminis var. tritici isolates from Washington State. Phytopathology 99:472479.

Madariaga, R., I. Matus, G. Rios, N. Arismendi, and E. MoyaElizondo. 2013. Unusual detection, molecular characterization and mycotoxigenic abilities of Fusarium isolated collected on Triticum durum heads in Chile during 2012-13 crop season. Abstract. International Symposium: Genetic and Breeding of Durum Wheat, Rome. 27-30 May. Accademia Nazionale delle Scienze, Rome, Italy.

Madariaga, R., y M. McMahon. 1981. Prospección del mal del pie (Gaeumannomyces graminis var. tritici) en la precordillera de Nuble y Bío-Bío. Simiente 51(1-2):28-32.

Madariaga, R., y M. Mellado. 1998. Efecto del precultivo de raps (Brassica napus L.) en la incidencia de mal del pie (Gaeumannomyces graminis var. tritici) en trigo. Agricultura Técnica 48:182-187.

Meza, F., and D. Silva. 2009. Dynamic adaptation of maize and wheat production to climate change. Climatic Change 94:143156. doi:10.1007/s10584-009-9544-z.

Montalva, C., N. Arismendi, M. Barta, and E. Rojas. 2014. Molecular differentiation of recently described Neozygites osornensis (Neozygitales: Neozygitaceae) from two morphologically similar species that infect aphids. Journal of Invertebrate Pathology 115:92-94

Moya-Elizondo, E. 2013. Fusarium crown rot disease: biology, interactions, management and function as a possible sensor of global climate change. Ciencia e Investigación Agraria 40:235252.

Moya-Elizondo, E., N.C. Cattan, N.L. Arismendi, and H.A. Doussoulin. 2013. Determination of 2,4-diacetylphloroglucinol (2,4-DAPG) and phenazine-producing Pseudomonas spp. in wheat crops in southern Chile. Phytopathology 103:S2.100.

Moya-Elizondo, E., B. Jacobsen, A.C. Hogg, and A.T. Dyer. 2011b. Population dynamics between Fusarium pseudograminearum and Bipolaris sorokiniana in wheat stems using real-time qPCR. Plant Disease 95:1089-1098.

Moya-Elizondo, E., R.L. Rew, B. Jacobsen, A.C. Hogg, and A.T. Dyer. 2011a. Distribution and prevalence of Fusarium crown rot and common root rot pathogens of wheat in Montana. Plant Disease 95:1099-1108.

Nelson, P.E., T.A. Toussoun, and W.F. Marasas. 1983. Fusarium species: An illustrated manual for identification. $226 \mathrm{p}$. The Pennsylvania State University Press, University Park, Pennsylvania, USA.

Neuenschwander, A. 2010. Cambio climático en el sector silvoagropecuario de Chile. Fundación para la Innovación Agraria (FIA). 126 p. Salviat Impresores S.A., Santiago, Chile.

Paulitz, T.C., R.W. Smiley, and R.J. Cook. 2002. Insight into the prevalence and management of soilborne cereal pathogens under direct seeding in the Pacific Northwest, USA. Canadian Journal of Plant Pathology 24:416-428.

Pettitt, T., X. Xu, and D. Parry. 2003. Association of Fusarium species in the wheat stem root complex. European Journal of Plant Pathology 109:769-774.

Rachdawong, S., C.L. Cramer, E.A. Grabau, V.K. Stromberg, G.H. Lacy, and E.L. Stromberg. 2002. Gaeumannomyces graminis vars. avenae, graminis, and tritici identified using PCR amplification of avenacinase-like genes. Plant Disease 86:652-660.

Saremi, H., A. Ammarellou, and H. Jafary. 2007. Incidence of crown rot disease of wheat caused by Fusarium pseudograminearum as a new soil born fungal species in North West Iran. Pakistan Journal of Biological Sciences 10:3606-3612.

Scott, J., O. Akinsami, V. Mitter, S. Simpfendorfer, R. Dill-Macky, and S. Chakraborty. 2003. Prevalence of Fusarium crown rot pathogens of wheat in southern Queensland and northern New South Wales. Fischer, R.A. et al. (eds.) New directions for a diverse planet: Proceedings of the $4^{\text {th }}$ International Crop Science Congress, Brisbane, Australia. 26 September-1 October 2004. The Regional Institute Ltd., Gosford, New South Wales, Australia.

Smiley, R.W., J.A. Gourlie, S.A. Easley, and L.M. Patterson. 2005. Pathogenicity of fungi associated with the wheat crown rot complex in Oregon and Washington. Plant Disease 89:949-957.

Soussana, J.F., A.I. Graux, and F.N. Tubiello. 2010. Improving the use of modelling for projections of climate change impacts on crops and pastures. Journal of Experimental Botany 61:22172228.

Strausbaugh, C.A., C.A. Bradley, A.C. Koehn, and R.L. Forster 2004. Survey of root diseases of wheat and barley in southeastern Idaho. Canadian Journal of Plant Pathology 26:167-176.

Tunali, B., J.M. Nicol, D. Hodson, Z. Uçkun, O. Büyük, D. Erdurmuş, et al. 2008. Root and crown rot fungi associated with spring, facultative, and winter wheat in Turkey. Plant Disease 92:1299-1306.

Van Ryckegem, G., and A. Verbeken. 2005. Fungal ecology and succession on Phragmites australis in a brackish tidal marsh. I. Leaf sheaths. Fungal Diversity 19:157-187.

Wagacha, J.M., and J.W. Muthomi. 2007. Fusarium culmorum: Infection process, mechanisms of mycotoxin production and their role in pathogenesis in wheat. Crop Protection 26:877-885. 